\title{
Appendix 2: Materials
}

\section{Experiment 1: Quantifier Scope}

\section{Unaccusatives:}

Verb: todok- $u$ 'arrive'

Surface description: はるみの友人のてるお、じゅんこ、そしてたくやは、夏休み にそれぞれ違う場所に旅行にでかけました。そして夏休み中に、てるおからは 絵葉書とかわいいキーホ ルダーが、じゅんこからは有名なお菓子と絵葉書が、 そしてたくやからは変わった $\mathrm{T}$ シャツと絵葉書が旅行先からはるみに送られて きました。

Inverse description: はるみの友人のてるお、じゅんこ、そしてたくやは、夏休み にそれぞれ違う場所に旅行にでかけました。そして夏休み中に、てるおからは 絵葉書とかわいいキーホ ルダーが、じゅんこからは有名なお菓子と絵葉書が、

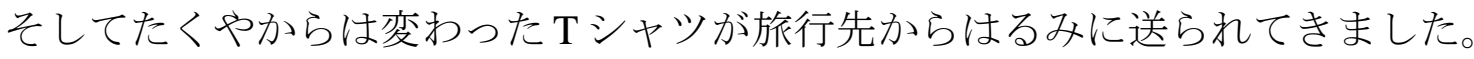
Question: 上の状況を、下の文章は正しく表現しているといえますか。

Target sentence:「夏休み中に何かがどの友達からも届いた。」

Verb: araware-ru 'appear'

Surface description: B 市の消防署には、消防士が常に三人勤務しています。昨日 は山田消防士と、鈴木消防士、そして斉藤消防士が、違うシフトでの出勤でし た。厳しい乾燥と強い風のため、昨日一日でB 市内で三ヶ所火災が起きました。 朝に起きた新明町の火事には山田消防士と鈴木消防士が、昼過ぎに起きた岸町 の火事では鈴木消防士と斉藤消防士が、そして夕方起きた公団住宅の火事には 山田消防士、鈴木消防士、そして斉藤消防士が出動しました。

Inverse description: B 市の消防署には、消防士が常に三人勤務しています。昨日 は山田消防士と、鈴木消防士、そして斉藤消防士が、違うシフトでの出勤でし た。㛜しい乾燥と強い風のため、昨日一日でB市内で三ヶ所火災が起きました。 朝に起きた新明町の火事には山田消防士と鈴木消防士が、昼過ぎに起きた岸町 の火事では鈴木消防士と斉藤消防士が、そして夕方起きた公団住宅の火事には 山田消防士と鈴木消防士が出動しました。

Question: 上の状況を、下の文章は正しく表現しているといえますか。

Target sentence:「昨日出勤の消防士の誰かがどの火災現場にも現れた。」 
Verb: $k u r-u$ 'come'

Surface description: A 大学の言語学部には、現在前田教授、村井教授、そして青 田教授の三名の教授が所属しています。今月は、言語学部関係の三つのイベン トがありました。第一週目のイベントには前田教授と青田教授が来て、第二週 目のイベントには村井教授と青田教授が来て、そして昨日あった集まりには前 田教授、村井教授、そして青田教授が顔を出しました。

Inverse description: A 大学の言語学部には、現在前田教授、村井教授、そして青 田教授の三名の教授が所属しています。今月は、言語学部関係の三つのイベン トがありました。第一週目のイベントには前田教授と青田教授が来て、第二週 目のイベントには村井教授と青田教授が来て、そして昨日あった集まりには前 田教授と村井教授が顔を出しました。

Question: 上の状況を、下の文章は正しく表現しているといえますか。 Target sentence:「今月は教授の誰かがどのイベントにも来た。」

Verb: nakunar-u 'disappear'

Surface description: たけしの会社には一階、二階、三階にそれぞれ一つづつ会議 室があります。ここ最近、会議室の物が無くなる事件が立て続けに起こりまし た。二週間前には三階の会議室から椅子が二つと時計が消え、先週は一階の会 議室から花瓶と時計が無くなり、そして今週の月曜日には二階の会議室の時計 も無くなってしまいました。

Inverse description: たけしの会社には一階、二階、三階にそれぞれ一つづつ会議 室があります。ここ最近、会議室の物が無くなる事件が立て続けに起こりまし た。二週間前には三階の会議室から椅子が二つが消え、先週は一階の会議室か ら花瓶と時計が無くなり、そして今週の月曜日には二階の会議室の時計も無く なってしまいました。

Question: 上の状況を、下の文章は正しく表現しているといえますか。 Target sentence:「過去二週間に何かがどの会議室からも無くなった。」

\section{Unergatives:}

Verb: hashir-u 'run'

Surface description: B 高校の陸上部のメンバーであるけんじ、てつお、そしてだ いきは、県大会で上位に入賞し、全国大会に出場することになりました。大会 第一日目の昨日は、 $100 \mathrm{~m}$ 走と $200 \mathrm{~m}$ 走、そして $100 \mathrm{~m}$ ハードルが行われました。 けんじは $100 \mathrm{~m}$ 走と $200 \mathrm{~m}$ 走に、てつおは $100 \mathrm{~m}$ ハードルに出場し、だいきは 100 $\mathrm{m}$ 走、 $200 \mathrm{~m}$ 走、そして $100 \mathrm{~m}$ ハードルに出場しました。 
Inverse description: B 高校の陸上部のメンバーであるけんじ、てつお、そしてだ いきは、県大会で上位に入賞し、全国大会に出場することになりました。大会 第一日目の昨日は、 $100 \mathrm{~m}$ 走と $200 \mathrm{~m}$ 走、そして $100 \mathrm{~m}$ ハードルが行われました。

けんじは $100 \mathrm{~m}$ 走に、てつおは $100 \mathrm{~m}$ ハードルに出場し、だいきは $200 \mathrm{~m}$ 走に出 場しました。

Question: 上の状況を、下の文章は正しく表現しているといえますか。

Target sentence:「大会初日にメンバーの誰かがどの種目でも走った。」

\section{Verb: hanas- $u$ 'talk'}

Surface description: A 町では、この数ヶ月連続放火事件が起き、ベテランの鈴木 警部をリーダーとして、山田刑事、斎藤刑事の三人による捜査班が設置されま した。警察が市民の捜査への協力を訴えた結果、最初の現場の近くに住む男子 大学生と、先週末ぼや騷ぎのあったアパートの管理人、そして三日前に駐車場 のゴミ捨て場に放火のあったスーパーの従業員が目撃者として名乗りを上げま した。男子大学生とアパートの管理人には山田刑事が話しを聞き、スーパーの 従業員には斎藤刑事が話しを聞きましたが、念のため鈴木刑事が大学生、管理 人、そしてスーパーの従業員にもう一度話しを聞きました。

Inverse description: A 町では、この数ヶ月連続放火事件が起き、ベテランの鈴木 警部をリーダーとして、山田刑事、斎藤刑事の三人による捜査班が設置されま した。警察が市民の捜査への協力を訴えた結果、最初の現場の近くに住む男子 大学生と、先週末ぼや騒ぎのあったアパートの管理人、そして三日前に駐車場 のゴミ捨て場に放火のあったスーパーの従業員が目撃者として名乗りを上げま した。男子大学生には山田刑事が話しを聞き、スーパーの従業員には斎藤刑事 が話しを聞き、鈴木刑事はアパートの管理人に話しを聞きました。

Question: 上の状況を、下の文章は正しく表現しているといえますか。

Target sentence:「聞き込みで捜査班の誰かがどの目撃者とも話した。」

\section{Verb: hatarak-u 'work'}

Surface description: 同じ高校に通う友人であるたけし、ひろし、そしてこうたの 三人は、「いなげや」と言う駅前のスーパーでアルバイトをしています。彼ら三 人は、主に野菜売り場、冷凍食品売り場、そしてお菓子売り場を担当していま す。今週はたけしが野菜売り場と冷凍食品売り場を担当し、ひろしは冷凍食品 売り場とお菓子売り場を、そしてこうたは野菜売り場と冷凍食品売り場、そし てお菓子売り場を担当しました。

Inverse description: 同じ高校に通う友人であるたけし、ひろし、そしてこうたの 三人は、「いなげや」と言う駅前のスーパーでアルバイトをしています。彼ら三 
人は、主に野菜売り場、冷凍食品売り場、そしてお菓子売り場を担当していま す。今週はたけしが野菜売り場を担当し、ひろしは冷凍食品売り場を、そして こうたがお菓子売り場を担当しました。

Question: 上の状況を、下の文章は正しく表現しているといえますか。

Target sentence: 「今週アルバイトの誰かが、どの売り場でも働いた。」

\section{Verb: $a s o b-u$ 'play'}

Surface description: ゆりちゃん、みのちゃん、そしてともちやんは、同じ幼稚園 に通うとても中の良いお友達です。いつも幼稚園が終わると、近所の公園で遊 んでから家に帰ります。この公園には、ブランコと滑り台、そしてジャングル ジムの三つの遊具があります。今日ゆりちゃんはブランコで遊び、みのちやん はブランコとジャングルジムで、そしてともちやんはブランコと滑り台、そし てジャングルジムで遊びました。

Inverse description: ゆりちゃん、みのちゃん、そしてともちゃんは、同じ幼稚園 に通うとても中の良いお友達です。いつも幼稚園が終わると、近所の公園で遊 んでから家に帰ります。この公園には、ブランコと滑り台、そしてジャングル ジムの三つの遊具があります。今日ゆりちゃんはブランコで遊び、みのちやん はジャングルジムで、そしてともちゃんは滑り台で遊びました。

Question: 上の状況を、下の文章は正しく表現しているといえますか。

Target sentence: 「三人の女の子の誰かがどの遊具でも遊んだ。」

\section{Transitives:}

\section{Verb: hanas- $u$ 'speak'}

Surface description: けんじ、よう子、そしてさおりは外国語学校の生徒です。彼 らの通う学校には、英語、中国語、韓国語、スペイン語のクラスがあります。 けんじは英語と韓国語を、よう子は英語とスペイン語を、そしてさおりは英語、 中国語、韓国語、そしてスペイン語を話します。

Inverse description: けんじ、よう子、そしてさおりは外国語学校の生徒です。彼 らの通う学校には、英語、中国語、韓国語、スペイン語のクラスがあります。 けんじは英語と韓国語を、よう子は英語とスペイン語を、そしてさおりは中国 語と韓国語を話します。

Question: 上の状況を、下の文章は正しく表現しているといえますか。 Target sentence:「三人の学生の誰かがどの言葉も話す。」 


\section{Verb: $n o m-u$ 'drink'}

Surface description: けんじ、ひろし、みのるは同じ大学に通う大学生です。先週 の週末は、お酒を持ち寄ってみのるの家で飲むことになりました。けんじは日 本酒を、ひろしはワインを、そしてみのるは焼酎を飲み会に持ってきました。 そしてけんじは日本酒を、ひろしは焼酎とワインを、そしてみのるは日本酒、 ワイン、そして焼酎を飲みました。

Inverse description: けんじ、ひろし、みのるは同じ大学に通う大学生です。先週 の週末は、お酒を持ち寄ってみのるの家で飲むことになりました。けんじは日 本酒を、ひろしはワインを、そしてみのるは焼酎を飲み会に持ってきました。 そしてけんじは日本酒を、ひろしは焼酎を、そしてみのるはワインと焼酎を飲 みました。

Question: 上の状況を、下の文章は正しく表現しているといえますか。

Target sentence:「飲夕会で誰かがどの種類の酒も飲んだ。」

\section{Verb: tabe-ru 'eat'}

Surface description: けい子は、父親のけんじと母親のさとこ、そして弟のみつお との四人暮らしです。昨日はみつおの誕生日だったので、けいこはケーキを、 父親のけんじはメロンを、そして母親のさとこはアイスクリームを買ってきま した。誕生日のみつおがケーキとアイスクリームとメロンを、けいこはケーキ とアイスクリームを食べ、父親のけんじと母親のさとこはアイスクリームを食 ベました。

Inverse description: けい子は、父親のけんじと母親のさとこ、そして弟のみつお との四人暮らしです。昨日はみつおの誕生日だったので、けいこはケーキを、 父親のけんじはメロンを、そして母親のさとこはアイスクリームを買ってきま した。誕生日のみつおがケーキとアイスクリームを、けいこはケーキを食べ、父 親のけんじと母親のさとこはメロンを食べました。

Question: 上の状況を、下の文章は正しく表現しているといえますか。

Target sentence:「家族の誰かがどのデザートも食べた。」

\section{Verb: $m i-r u$ 'watch'}

Surface description: みちこ、ひろみ、そしてまさえは、週末に3つの映画を上映 している映画館へいきました。当日上映していた映画は、「悪魔の金曜日」、「ラ 一メン物語」、そして「スターバトル」と言う作品でした。三人はそれぞれ見た い映画を、ばらばらに見ることに決めました。みちこは「悪魔の金曜日」と「ス ターバトル」を、ひろ夕は「ラーメン物語」を二回見て、まさえは「悪魔の金 曜日」と「ラーメン物語」と「スターバトル」を見ました。 
Inverse description: みちこ、ひろみ、そしてまさえは、週末に3つの映画を上映 している映画館へいきました。当日上映していた映画は、「悪魔の金曜日」、「ラ 一メン物語」、そして「スターバトル」と言う作品でした。三人はそれぞれ見た い映画を、ばらばらに見ることに決めました。みちこは「悪魔の金曜日」を、 ひろみは「ラーメン物語」を見て、まさえ「スは「スターバトル」を見ました。 Question: 上の状況を、下の文章は正しく表現しているといえますか。

Target sentence:「映画館で誰かがどの映画も見た。」 


\section{Experiment 2: FNQ-licensing}

\section{List 1}

[class1, enter, -FNQ]

顧問の新任教師は一年生の男子学生が八人新設のラクロス部に入ったことを報 告した。

[class1, enter, +FNQ]

目撃者の女性は暴力団風の男が駅前の銀行に三人入ったのを不思議に思った。 [class1, fall, -FNQ]

遊園地の警備員はふざけた小学生が四人公園の大きな池に落ちたことを報告し た。

[class1, fall, +FNQ]

幼稚園の先生は遊んでいた園児が滑り台の上から五人落ちたことを知っていた。 [class2, disappear, -FNQ]

初老の事務員は若い新入社員が二人宴会会場から消えたことを報告した。

[class2, disappear, +FNQ]

クラスの学級委員はクラスの女子学生が遠足のバスから二人消えたことを知っ ていた。

[class2, appear, -FNQ]

張り込み中の刑事は怪しい中年男性が二人殺人事件の現場に現れたことを報告 した。

[class2, appear, +FNQ]

若手の新聞記者は著名な政治家がその料亭から四人現れたことを知っていた。

[class3, be, -FNQ]

ベテランの体育教師は三年生の男子が四人体育館の裏にいたことを報告した。

[class3, be, + FNQ]

レスキュー隊の隊員は逃げ遅れた老人が崩れたアパートの中に七人いたことを 知っていた。

[class3, remain, -FNQ]

選手団の団長は日本の選手が三人トーナメントの準決勝に残ったことを報告し た。

[class3, remain, +FNQ]

幹事を務めた男性は同じ課の同僚が新年会会場の飲み屋に二人残ったことを知 つていた。

[class4, dance, -FNQ] 
ダンス部の顧問は三年生の部員が三人全国大会の舞台で踊ったことを報告した。 [class4, dance, $+\mathrm{FNQ}]$

バレー教室の先生は中学生の生徒がろくに練習せず二人踊ったことを知ってい た。

[class4, swim, -FNQ]

交番の警察官は川に落ちた酔っ払いが三人下手な背泳ぎで泳いだことを報告し た。

[class4, dance, $+\mathrm{FNQ}]$

スイミングクラブの先生は低学年の子どもが準備運動抜きで五人泳いだことを 知っていた。

[class5, work, -FNQ]

中年の工場長は若い新入社員が五人休日返上で働いたことを報告した。

[class5, work, +FNQ]

建築現場の監督はベテランの作業員が炎天下の中で四人働いたことを知ってい た。

[class5, play, -FNQ]

心理学部の学生は実験に参加した子どもが五人一つのおもちゃで遊んだことを 報告した。

[class5, play, +FNQ]

幼稚園の園長は年少組の子供たちが近所の公園で六人遊んだことを知っていた。

\section{List 2}

[class1, enter, -FNQ]

付き添いの父兄は年長組の男の子が五人幼児用のプールに入ったのを喜んだ。 [class1, enter, +FNQ]

顧問の新任教師は一年生の男子学生が新設のラクロス部に八人入ったことを報 告した。

[class1, fall, -FNQ]

近所のいたずら小僧は通りがかりの男性が三人掘った落とし穴に落ちたのを喜 んだ。

[class1, fall, +FNQ]

遊園地の警備員はふざけた小学生が公園の大きな池に四人落ちたことを報告し た。

[class2, disappear, -FNQ]

熱狂的なファンは不調の選手が三人一軍のメンバーから消えたのを喜んだ。 
[class2, disappear, +FNQ]

初老の事務員は若い新入社員が宴会会場から二人消えたことを報告した。

[class2, appear, -FNQ]

野球部の部員達は引退した先輩が五人決勝戦の応援に現れたのを喜んだ。

[class2, appear, +FNQ]

張り込み中の刑事は怪しい中年男性が殺人事件の現場に二人現れたことを報告 した。

[class3, be, -FNQ]

新しいレストランの店長は席を待つ客が十人レストランの前にいたのを喜んだ。 [class3, be, $+\mathrm{FNQ}$ ]

ベテランの体育教師は三年生の男子が体育館の裏に四人いたことを報告した。

[class3, remain, -FNQ]

サッカー部のコーチは今年の新入部員が十人㛜しい合宿の後に残ったのを喜ん だ。

[class3, remain, +FNQ]

選手団の団長は日本の選手がトーナメントの準決勝に三人残ったことを報告し た。

[class4, dance, -FNQ]

会場の保護者達はバレー教室の子どもが八人間違え一つなく踊ったのを喜んだ。 [class4, dance, + FNQ]

ダンス部の顧問は三年生の部員が全国大会の舞台で三人踊ったことを報告した。 [class4, swim, -FNQ]

熱心なファン達は有名な水泳選手が二人地元の水泳大会で泳いだのを喜んだ。

[class4, swim, +FNQ]

交番の警察官は川に落ちた酔っ払いが下手な背泳ぎで三人泳いだことを報告し た。

[class5, work, -FNQ]

コンビニの店長は留学生のアルバイトが三人とても真面目に働いたのを喜んだ。 [class5, work, +FNQ]

中年の工場長は若い新入社員が休日返上で五人働いたことを報告した。

[class5, play, -FNQ]

保育園の保母さんは初めて会った幼児が三人とても仲良く遊んだのを喜んだ。 [class5, play, +FNQ]

心理学部の学生は実験に参加した子どもが一つのおもちゃで五人遊んだことを 報告した。 


\section{List 3}

[class1, enter, -FNQ]

目撃者の女性は暴力団風の男が三人駅前の銀行に入ったのを不思議に思った。

[class1, enter, $+\mathrm{FNQ}$ ]

付き添いの父兄は年長組の男の子が幼児用のプールに五人入ったのを喜んだ。 [class1, fall, -FNQ]

若い現場監督はベテランの職人が二人二階の足場から落ちたのを不思議に思っ た。

[class1, fall, +FNQ]

近所のいたずら小僧は通りがかりの男性が掘った落とし穴に三人落ちたのを喜 んだ。

[class2, disappear, -FNQ]

夕刊紙の芸能記者は若手のお笑い芸人が四人その人気番組から消えたのを不思 議に思った。

[class2, disappear, +FNQ]

熱狂的なファンは不調の選手が一軍のメンバーから三人消えたのを喜んだ。

[class2, appear, -FNQ]

ベテランの消防署員は黒装束の男性が三人火災の現場に現れたのを不思議に思 つた。

[class2, appear, +FNQ]

野球部の部員達は引退した先輩が決勝戦の応援に五人現れたのを喜んだ。

[class3, be, -FNQ]

通りがかりの主婦は高校生らしき女の子が二人ラーメン屋の駐車場にいたのを 不思議に思った。

[class3, be, $+\mathrm{FNQ}$ ]

新しいレストランの店長は席を待つ客がレストランの前に十人いたのを喜んだ。 [class3, remain, -FNQ]

バレー部の先生はバスケット部の部員が五人部活終了後の体育館に残ったのを 不思議に思った。

[class3, remain, $+\mathrm{FNQ}$ ]

サッカー部のコーチは今年の新入部員が厳しい合宿の後に十人残ったのを喜ん だ。

[class4, dance, -FNQ]

地元のレポーターは見かけない男女が五人祭りのステージで踊ったのを不思議 に思った。 
[class4, dance, $+\mathrm{FNQ}]$

会場の保護者達はバレー教室の子どもが間違え一つなく八人踊ったのを喜んだ。 [class4, swim, -FNQ]

ベテランのコーチは三年生の選手が四人ひどいタイムで泳いだのを不思議に思 つた。

[class4, swim, +FNQ]

熱心なファン達は有名な水泳選手が地元の水泳大会で二人泳いだのを喜んだ。

[class5, work, -FNQ]

回転寿司の主人は最近入った従業員が二人かなりの厚着で働いたのを不思議に 思った。

[class5, work, +FNQ]

コンビニの店長は留学生のアルバイトがとても真面目に三人働いたのを喜んだ。 [class5, play, -FNQ]

担任の教師はクラスの女の子が四人教室の中で遊んだのを不思議に思った。

[class5, play, +FNQ]

保育園の保母さんは初めて会った幼児がとても仲良く三人遊んだのを喜んだ。

\section{List 4}

[class1, enter, -FNQ]

駄菓子屋の主人は中学生ぐらいの男の子が四人近所のパチンコ屋に入ったこと を知っていた。

[class1, enter, +FNQ]

目撃者の女性は暴力団風の男が駅前の銀行に三人入ったのを不思議に思った。 [class1, fall, -FNQ]

幼稚園の先生は遊んでいた園児が五人滑り台の上から落ちたことを知っていた。 [class1, fall, +FNQ]

若い現場監督はベテランの職人が二階の足場から二人落ちたのを不思議に思っ た。

[class2, disappear, -FNQ]

クラスの学級委員はクラスの女子学生が二人遠足のバスから消えたことを知っ ていた。

[class2, disappear, +FNQ]

夕刊紙の芸能記者は若手のお笑い芸人がその人気番組から四人消えたのを不思 議に思った。 
[class2, appear, -FNQ]

若手の新聞記者は著名な政治家が四人その料亭から現れたことを知っていた。 [class2, appear, +FNQ]

ベテランの消防署員は黒装束の男性が火災の現場に三人現れたのを不思議に思 つた。

[class3, be, -FNQ]

レスキュー隊の隊員は逃げ遅れた老人が七人崩れたアパートの中にいたことを 知っていた。

[class3, be, $+\mathrm{FNQ}]$

通りがかりの主婦は高校生らしき女の子がラーメン屋の駐車場に二人いたのを 不思議に思った。

[class3, remain, -FNQ]

幹事を務めた男性は同じ課の同僚が二人新年会会場の飲み屋に残ったことを知 っていた。

[class3, remain, $+\mathrm{FNQ}]$

バレー部の先生はバスケット部の部員が部活終了後の体育館に五人残ったのを 不思議に思った。

[class4, dance, -FNQ]

バレー教室の先生は中学生の生徒が二人ろくに練習せず踊ったことを知ってい た。

[class4, dance, + FNQ]

地元のレポーターは見かけない男女が祭りのステージで五人踊ったのを不思議 に思った。

[class4, swim, -FNQ]

スイミングクラブの先生は低学年の子どもが五人準備運動抜きで泳いだことを 知っていた。

[class4, swim, +FNQ]

ベテランのコーチは三年生の選手がひどいタイムで四人泳いだのを不思議に思 つた。

[class5, work, -FNQ]

建築現場の監督はベテランの作業員が四人炎天下の中で働いたことを知ってい た。

[class5, work, +FNQ]

回転寿司の主人は最近入った従業員がかなりの厚着で二人働いたのを不思議に 思った。

[class5, play, -FNQ] 
幼稚園の園長は年少組の子供たちが六人近所の公園で遊んだことを知っていた。 [class5, play, $+\mathrm{FNQ}$ ]

担任の教師はクラスの女の子が教室の中で四人遊んだのを不思議に思った。 


\section{Experiment 3: FNQ-licensing with animacy and telicity}

\section{List 1}

[enter, lexicalization 1, +animate, $+\mathrm{FNQ}$ ]

総務部の部長は人事課の課長から新しい職員が新設の開発部に 3 人入ったと聞 いた。

[enter, lexicalization 2, +animate, -FNQ]

張り込み中の刑事は捜査一課の課長に中年男性が 2 人容疑者の店に入ったと報 告した。

[fall, lexicalization 3, -animate, +FNQ]

現場の責任者は駆けつけた救急隊員に運搬中の材木が作業員の上に 2 本落ちた と説明した。

[fall, lexicalization 4, -animate, -FNQ]

美術館の職員は出張中の館長に中国のつぼが 1 つ展示されていた棚から落ちた と連絡した。

[disappear, lexicalization $1,+$ animate, $+\mathrm{FNQ}]$

ニュース番組のスタッフはプロデューサーにロシア人のジャーナリストが記者 会見の会場から 2 人消えたとイーメールした。

[disappear, lexicalization 2, +animate, -FNQ]

ゴシップ番組の司会者は先週の放送で若手のお笑いタレントが 3 人ゴールデン タイムの人気番組から消えたことを話題にした。

[appear, lexicalization 3, -animate, +FNQ]

開発部の技術者は製品開発チームのリーダーに改善困難な問題が改良中の新製 品に 2 つ現れたと報告した。

[appear, lexicalization 4, -animate, -FNQ]

スーパーの店長は交番の警官に中身不明のダンボール箱が 3 つ開店前の店の入

りロに現れたと証言した。

[be, lexicalization 1, +animate, $+\mathrm{FNQ}$ ]

大学のスカウト担当は野球チームの監督に将来有望な選手が地元高校の野球部 に 2 人いたと報告した。

[be, lexicalization 2, +animate, -FNQ]

見回りの父兄は中学校の教頭先生に行動不審な男子学生が放課後の体育館裏に 4 人いたことを話した。

[remain, lexicalization 3, -animate, $+\mathrm{FNQ}$ ]

幹事の新入社員は酒好きの上司に購入したビールが忘年会終了後に 8 本残った 
と報告した。

[remain, lexicalization 4, -animate, -FNQ]

アルバイトの販売員はケーキ屋の店長にクリスマスケーキが 10 箱午後九時の 閉店後に残ったと話した。

[dance, lexicalization1, +telic, +FNQ]

事件があったクラブの従業員は捜査員に酔っ払った会社員が朝の四時まで 4 人 踊ったと証言した。

[dance, lexicalization 2, +telic, -FNQ]

ダンス教室の先生は付き添いの保護者に教室の生徒が 5 人午前中の間に踊った と話した。

[swim, lexicalization 3, -telic, +FNQ]

夜勤の警備員はその日の報告書に酒を飲んだ大学生が中学校のプールで 4 人泳 いだと書いた。

[swim, lexicalization 4, -telic, -FNQ]

初老のツアーガイドは仕事仲間にとても高龄のご老人が 8 人ホテルのプールで 泳いだと話した。

[work, lexicalization $1,+$ telic, $+\mathrm{FNQ}$ ]

倉庫の責任者は心配した社長に大学生のアルバイトが翌日の朝まで 6 人働いた と説明した。

[work, lexicalization 2, +telic, -FNQ]

やり手の弁護士は地元の衣服工場で不法就労者が 4 人半年の間に働いた事実を 突き止めた。

[play, lexicalization 3, -telic, $+\mathrm{FNQ}$ ]

ベテランの先生は保育園の園長に公園の砂場で年長組の子供達がとても仲良く 6 人遊んだと話した。

[play, lexicalization 4, -telic, -FNQ]

学童保育の指導員は責任者の教師に風邪気味の子ども達が 4 人教室の中で遊ん だと報告した。

\section{List 2}

[enter, lexicalization 2, +animate, $+\mathrm{FNQ}]$

張り込み中の刑事は捜査一課の課長に中年男性が容疑者の店に 2 人入ったと報 告した。

[enter, lexicalization 1, +animate, -FNQ]

総務部の部長は人事課の課長から新しい職員が 3 人新設の開発部に入ったと聞 
いた。

[fall, lexicalization 4, -animate, $+\mathrm{FNQ}$ ]

美術館の職員は出張中の館長に中国のつぼが展示されていた棚から 1 つ落ちた と連絡した。

[fall, lexicalization 3, -animate, -FNQ]

現場の責任者は駆けつけた救急隊員に運搬中の材木が 2 本作業員の上に落ちた と説明した。

[disappear, lexicalization 2, +animate, + FNQ]

ゴシップ番組の司会者は先週の放送で若手のお笑いタレントがゴールデンタイ ムの人気番組から 3 人消えたことを話題にした。

[disappear, lexicalization 1, +animate, -FNQ]

ニュース番組のスタッフはプロデューサーにロシア人のジャーナリストが 2 人 記者会見の会場から消えたとメールした。

[appear, lexicalization 4, -animate, +FNQ]

スーパーの店長は交番の警官に中身不明のダンボール箱が開店前の店の入り口 に 3 つ現れたと証言した。

[appear, lexicalization 3, -animate, -FNQ]

開発部の技術者は製品開発チームのリーダーに改善困難な問題が 2 つ改良中の 新製品に現れたと報告した。

[be, lexicalization 2, +animate, $+\mathrm{FNQ}]$

見回りの父兄は中学校の教頭先生に行動不審な男子学生が放課後の体育館裏に 4 人いたことを話した。

[be, lexicalization 1, +animate, -FNQ]

大学のスカウト担当は野球チームの監督に将来有望な選手が 2 人地元高校の野 球部にいたと報告した。

[remain, lexicalization 4, -animate, $+\mathrm{FNQ}$ ]

アルバイトの販売員はケーキ屋の店長にクリスマスケーキが午後九時の閉店後 に 10 箱残ったと話した。

[remain, lexicalization 3, -animate, -FNQ]

幹事の新入社員は酒好きの上司に購入したビールが 8 本忘年会終了後に残った と報告した。

[work, lexicalization 2, +telic, +FNQ]

やり手の弁護士は地元の衣服工場で不法就労者が半年の間に 4 人働いた事実を 突き止めた。

[work, lexicalization 1, +telic, -FNQ]

倉庫の責任者は心配した社長に大学生のアルバイトが 6 人翌日の朝まで働いた 
と説明した。

[play, lexicalization 4, -telic, +FNQ]

学童保育の指導員は責任者の教師に風邪気味の子ども達が教室の中で 4 人遊ん だと報告した。

[play, lexicalization 3, -telic, -FNQ]

ベテランの先生は保育園の園長に公園の砂場で年長組の子供達が 6 人とても仲 良く遊んだと話した。

[dance, lexicalization $2,+$ telic, + FNQ]

ダンス教室の先生は付き添いの保護者に教室の生徒が午前中の間に 5 人踊った と話した。

[dance, lexicalization 1, +telic, -FNQ]

事件があったクラブの従業員は捜査員に酔っ払った会社員が 4 人朝の四時まで 踊ったと証言した。

[swim, lexicalization 4, -telic, +FNQ]

初老のツアーガイドは仕事仲間にとても高齢のご老人がホテルのプールで 8 人 泳いだと話した。

[swim, lexicalization 3, -telic, -FNQ]

夜勤の警備員はその日の報告書に酒を飲んだ大学生が 4 人中学校のプールで泳 いだと書いた。

\section{List 3}

[enter, lexicalization 3, -animate, $+\mathrm{FNQ}]$

案内係のアルバイトは駐車場のオーナーに花見客の車が駐車場の二階に 5 台入 ったと連絡した。

[enter, lexicalization 4, -animate, -FNQ]

引越し屋の従業員は客の中年夫婦に新しい洋服ダンスが 2 二階の寝室に入っ たと言った。

[fall, lexicalization 1, +animate, $+\mathrm{FNQ}$ ]

サーカスの責任者は地元テレビ局の記者にベテランの軽業師が崩れたステージ から 3 人落ちたと証言した。

[fall, lexicalization 2, +animate, -FNQ]

新任の駅長はベテランの駅員から電話中の乗客が 2 人二番線のプラットホーム から落ちたと報告を受けた。

[disappear, lexicalization 3, -animate, $+\mathrm{FNQ}$ ]

真面目な新入社員は同じ課の同僚に来客用のケーキが休惒室の冷蔵庫から 4 つ 
消えたと話した。

[disappear, lexicalization 4, -animate, -FNQ]

アルバイトの大学生は古本屋の店長に人気のマンガ本が 2 冊飾ってあった棚か ら消えたと報告した。

[appear, lexicalization 1, +animate, $+\mathrm{FNQ}$ ]

サッカー部のキャプテンは顧問の先生に元部員の 2 年生が県大会の試合会場に 4 人現れたと言った。

[appear, lexicalization 2, +animate, -FNQ]

受付係の社員がやり手の若社長に入社希望の学生が 5 人一階の面接会場に現れ たと連絡した。

[be, lexicalization 3, -animate, + FNQ]

大学生のコーチはリトルリーグの監督に持ち主不明のスポーツバッグが練習後 のグラントに 3 つったと言った。

[be, lexicalization 4, -animate, -FNQ]

小学三年生の女の子は迎えに来た母親に面白そうな本が 5 冊学校の図書館にあ ったとい言った。

[remain, lexicalization 1, +animate, +FNQ]

付き添いの父兄はそろばん塾の塾長に六年生の生徒が珠算大会の決勝戦に 2 人 残ったと報告した。

[remain, lexicalization 2, +animate, -FNQ]

柔道部の顧問の先生は剣道部の顧問の先生に今年の新入部員が 10 人㛜しい合 宿の後に残ったと自慢した。

[dance, lexicalization 3, -telic, +FNQ]

祭りの運営委員会はその町の町長にゲストの留学生が祭りのステージで 6 人踊 ったと言った。

[dance, lexicalization 4, -telic, -FNQ]

ニューヨーク支部の新聞記者は日本の本社に日本の中学生が 4 人ダンスの世界 選手権で踊ったと報告した。

[swim, lexicalization 1, +telic, +FNQ]

引率の教師は学年代表の教師に無鉄砲な男子学生が川の反対まで 2 人泳いだと 報告した。

[swim, lexicalization 2, +telic, -FNQ]

代表チームのコーチはテレビのレポーターに日本の選手が 3 人午前中の間に泳 いだと言った。

[work, lexicalization 3, -telic, +FNQ]

加工食品部の責任者はスーパーの店長に昨日入った男子社員がだらだらと 2 人 
働いたと文句を言った。

[work, lexicalization 4, -telic, -FNQ]

公園管理課の職員は公園をきれいにするイベントでボランティアの中学生が 8 人頑張って働いたと褒めた。

[play, lexicalization 1, +telic, + FNQ]

ゲームセンターの従業員は父兄の一人にその日近所の団地の小学生が閉店の時 間まで 5 人遊んだと話した。

[play, lexicalization 2, +telic, -FNQ]

市民プールの監視員は先輩の監視員に幼児プールで近所の幼稚園生が 10 人二 時間の間に遊んだと報告した。

\section{List 4}

[enter, lexicalization 4, -animate, +FNQ]

引越し屋の従業員は客の中年夫婦に新しい洋服ダンスが二階の寝室に 2 つつ たと言った。

[enter, lexicalization 3, -animate, -FNQ]

案内係のアルバイトは駐車場のオーナーに花見客の車が 5 台駐車場の二階に入 ったと連絡した。

[fall, lexicalization 2, +animate, +FNQ]

新任の駅長はベテランの駅員から電話中の乗客が二番線のプラットホームから 2 人落ちたと報告を受けた。

[fall, lexicalization 1, +animate, -FNQ]

サーカスの責任者は地元テレビ局の記者にベテランの軽業師が 3 人崩れたステ ージから落ちたと証言した。

[disappear, lexicalization 4, -animate, $+\mathrm{FNQ}$ ]

アルバイトの大学生は古本屋の店長に人気のマンガ本が飾ってあった棚から 2 冊消えたと報告した。

[disappear, lexicalization 3, -animate, -FNQ]

真面目な新入社員は同じ課の同僚に来客用のケーキが 4 つ休憩室の冷蔵庫から 消えたと話した。

[appear, lexicalization 2, +animate, + FNQ]

受付係の社員がやり手の若社長に入社希望の学生が一階の面接会場に 5 人現れ たと連絡した。

[appear, lexicalization 1, +animate, -FNQ]

サッカー部のキャプテンは顧問の先生に元部員の 2 年生が 4 人県大会の試合会 
場に現れたと言った。

[be, lexicalization 4, -animate, $+\mathrm{FNQ}]$

小学三年生の女の子は迎えに来た母親に面白そうな本が学校の図書館に 5 冊あ ったとい言った。

[be, lexicalization 3, -animate, -FNQ]

大学生のコーチはリトルリーグの監督に持ち主不明のスポーツバッグが 3 つ練 習後のグラントにあったと言った。

[remain, lexicalization 2, +animate, $+\mathrm{FNQ}$ ]

柔道部の顧問の先生は剣道部の顧問の先生に今年の新入部員が厳しい合宿の後 に 10 人残ったと自慢した。

[remain, lexicalization 1, +animate, -FNQ]

付き添いの父兄はそろばん塾の塾長に六年生の生徒が 2 人珠算大会の決勝戦に 残ったと報告した。

[work, lexicalization 4, -telic, +FNQ]

公園管理課の職員は公園をきれいにするイベントでボランティアの中学生が頑 張って 8 人働いたと褒めた。

[work, lexicalization 3, -telic, -FNQ]

加工食品部の責任者はスーパーの店長に昨日入った男子社員が 2 人だらだらと 働いたと文句を言った。

[play, lexicalization 2, +telic, $+\mathrm{FNQ}$ ]

市民プールの監視員は先輩の監視員に幼児プールで近所の幼稚園生が二時間の 間に 10 人遊んだと報告した。

[play, lexicalization 1, +telic, -FNQ]

ゲームセンターの従業員は父兄の一人にその日近所の団地の小学生が 5 人閉店 の時間まで遊んだと話した。

[dance, lexicalization 4, -telic, +FNQ]

ニューヨーク支部の新聞記者は日本の本社に日本の中学生がダンスの世界選手 権で 4 人踊ったと報告した。

[dance, lexicalization 3, -telic, -FNQ]

祭りの運営委員会はその町の町長にゲストの留学生が 6 人祭りのステージで踊 ったと言った。

[swim, lexicalization 2, +telic, +FNQ]

代表チームのコーチはテレビのレポーターに日本の選手が午前中の間に 3 人泳 いだと言った。

[swim, lexicalization 1, +telic, -FNQ]

引率の教師は学年代表の教師に無鉄砲な男子学生が 2 人川の反対まで泳いだと報告 
した。 